\title{
Biodiversitas dan Identifikasi Jamur Basidiomycetes di Taman Nasional Sebangau, Kabupaten Katingan Kalimantan Tengah
}

\author{
Patricia E. Putir ${ }^{1 *}$, Yusintha Tanduh ${ }^{1}$ dan Eritha K. Firdara ${ }^{1}$ \\ (123) Jurusan Kehutanan Fakultas Pertanian Universitas Palangka Raya \\ *patricia@for.upr.ac.id
}

\begin{abstract}
Abstrak
Masyarakat yang tinggal di sekitar hutan, pada umumnya sangat bergantung pada hasil hutan, baik itu hasil hutan berupa kayu maupun hasil hutan yang bukan berupa kayu. Kebutuhan masyarakat akan hasil hutan khususnya hasil hutan non kayu seperti damar, kemenyan, jamur, madu hutan serta produk lainnya akan semakin berkurang dengan beralihnya fungsi lahan hutan. Jamur merupakan salah satu produk hasil hutan non kayu yang paling disukai karena dapat dicari dengan mudah. Tujuan penelitian ini adalah untuk mengetahui jenis-jenis jamur Basidiomycetes serta untuk mengetahui jenis jamur pangan dan jamur obat yang ada di kawasan penelitian Punggualas Taman Nasional Sebangau. Metode penelitian yang digunakan adalah dengan metode eksplorasi dan identifikasi dengan membuat plot ukuran $150 \mathrm{~m}$ x $100 \mathrm{~m}$ dengan jalur pengamatan jamur sebanyak 5 jalur, jarak antar jalur adalah $5 \mathrm{~m}$ dan lebar jalur $20 \mathrm{~m}$. Hasil penelitian ditemukan 15 famili jamur Basidiomycetes, 49 jenis jamur dan jumlah individu jamur sebanyak 789 buah. Berdasarkan jumlah individu maka jamur Aucularia auricula merupakan jamur yang dominan tumbuh di Taman Nasional Sebangau. Indeks keanekaragaman $\left(\mathrm{H}^{\prime}\right)=2,6260$ tergolong sedang. Indeks kekayaan $\mathrm{R}=7,1956$ tergolong tinggi dan indeks kemerataan E1=0,6747 tergolong sedang. Jamur Auricularia auricula (jamur kuping/kulat bitak) dan Pleurotus sp. (jamur tiram/kulat puti) termasuk jamur yang dapat dikonsumsi dan jamur Ganoderma applanatum termasuk jamur yang dapat digunakan sebagai bahan obat. Substrat jamur .
\end{abstract}

Kata kunci: Jamur, Basidiomycetes, Biodiversitas, Taman Nasional Sebangau

\section{Pendahuluan}

Salah satu sumber kekayaan hayati di hutan tropis Indonesia adalah jamur atau yang sering disebut sebagai jamur makro (macro fungi). Peran penting dari jamur adalah dalam siklus biogeo, kimia tanah, siklus hara, sebagai pengurai (pendekomposer), fungsi simbion pada tanaman yang bersifat saling menguntungkan atau bersifat merugikan yaitu sebagai parasit bagi hewan maupun tumbuhan. Selain itu, jamur juga mempunyai nilai ekonomi sebagi agen biokontrol dan produser bagi industri farmasi serta industri lainnya seperti industri pangan dan fermentasi.

Terdapat tiga (3) kelompok besar yang sering diamati dan diteliti oleh manusia yaitu Ascomycotina, Basidiomycotina dan Deuteromycotina yang juga sering disebut jamur makro sesungguhnya (fungi).

Masyarakat yang tinggal di sekitar hutan, pada umumnya sangat bergantung pada hasil hutan, baik itu hasil hutan berupa kayu maupun hasil hutan yang bukan berupa kayu. Kebutuhan masyarakat akan hasil hutan khususnya hasil hutan non kayu seperti damar, kemenyan, jamur, madu hutan serta produk lainnya akan semakin berkurang dengan beralihnya fungsi lahan hutan. Jamur merupakan salah satu produk hasil hutan non kayu yang paling disukai karena dapat dicari dengan mudah.

Penelitian mengenai jamur dari kelas Basidiomycetes yang berpotensi sebagai jamur pangan dan jamur obat belum banyak diketahui informasinya yang kemungkinan memiliki manfaat lebih besar bagi kehidupan masyarakat di sekitar hutan. Oleh karena itu penelitian ini merupakan penelitian awal yang dapat memberikan informasi terkait potensi jenis-jenis jamur pangan dan jamur obat yang terdapat di kawasan penelitian tersebut. 


\section{Bahan dan Alat}

Bahan yang digunakan adalah kertas label, tubuh buah jamur yang diambil dengan ukuran $\varnothing$ tudung minimal 3 sampai $10 \mathrm{~cm}$. Alat yang digunakan untuk penelitian adalah: GPS, meteran, tali nilon, spidol permanen, ice box, penggaris plastik, parang, pisau cutter, kamera digital dan Tally sheet.

\section{Metode}

Lokasi penelitian adalah plot semi permanen yang telah dilakukan sebelumnya, namun pengambilan sampel hanya dilakukan pada luasan plot $150 \mathrm{~m}$ x $100 \mathrm{~m}$ dengan jalur pengamatan jamur sebanyak 5 jalur, jarak antar jalur adalah $5 \mathrm{~m}$ dan lebar jalur $20 \mathrm{~m}$

Data yang diambil adalah dengan melakukan pengumpulan (koleksi) jamur secara sensus (100 $\%$ ). Jenis jamur yang diambil adalah yang bertubuh buah besar (mushroom/macro fungi) baik yang tumbuh di tanah, serasah, pohon hidup dan kayu mati. Jamur yang terlalu kecil tubuh buahnya tidak diambil karena kesulitan dalam pengeringan dan identifikasinya. Jamur yang belum diketahui jenisnya dilakukan pengeringan dengan menggunakan oven, dan dibawa ke Palangka Raya. Jamur yang dapat diidentifikasi dilakukan dalam keadaan masih segar, karena bila sudah kering warna dan ukurannya bisa berubah. Data yang dicatat adalah:

1. Jenis jamur yang ditemukan, yaitu dengan menentukan nama jenis jamur secara langsung di lapangan.

2. Karakteristik jamur, yaitu mendeskripsikan sifat morfologis tubuh buah jamur melalui pengamatan dan pengukuran terhadap: tudung (cap, pileus) dan tangkai (stem, stipe): ukuran, bentuk, warna, permukaan, tekstur dan kelembapan/kebasahan; insang (gills, lamellae): warna, alat tambahan; cincin (annulus): ada atau tidak dan bentuknya; daging (flesh): warna, tekstur; cawan (volva): ada atau tidak dan bentuknya; spora (spore): ukuran, bentuk dan warna serta bau (odor). [1-4]

3. Substrat jamur, yaitu tanah, serasah, kayu mati atau pohon hidup.

4. Peranan jamur tersebut, apakah bisa dimakan, atau dipergunakan sebagai obat

\section{Analisis Data}

Untuk mengetahui kelimpahan maka dilakukan perhitungan sebagai berikut:

Indeks Keanekaragaman Jenis $(H)$

Penentuan keanekaragaman jenis yang juga menunjukkan tingkat kestabilan dari jenis jamur tersebut, digunakan rumus indeks keanekaragaman jenis menurut Odum (1993) dalam Bratawinata (2001) sebagai berikut:

$$
\begin{array}{ll} 
& \mathrm{H}^{\prime}=-\sum\left(\frac{n i}{N}\right) \log \left(\frac{n i}{N}\right) \\
\text { Keterangan : } & \mathrm{H}^{\prime}=\text { Indeks Keanekaragaman } \\
& \mathrm{ni}=\text { Jumlah Individu Tiap Jenis } \\
& \mathrm{N}=\text { Jumlah Individu Seluruh Jenis }
\end{array}
$$

\section{Indeks Kekayaan $(R)$}

Penentuan kekayaan jenis jamur pada setiap plot penelitian, digunakan Indeks Kekayaan dengan rumus berikut:

$$
\mathrm{R}=\frac{\mathrm{S}-1}{\ln (\mathrm{N})}
$$

Keterangan:

$\mathrm{S}=$ jumlah jenis fungi makro yang teramati

$\mathrm{N}=$ jumlah seluruh individu fungi makro

ln = Logaritma natural

Indeks Kemerataan (e) 
Menentukan apakah individu-individu terdistribusi secara lebih merata pada jenis-jenis yang hadir pada suatu tingkat pertumbuhan, dapat menggunakan Indeks Kemerataan (e) menurut Odum (1993) dalam Bratawinata (2001) dengan rumus sebagai berikut :

$$
\mathrm{e}=\frac{\mathrm{H}}{\log \mathrm{S}}
$$

Keterangan : e = Indeks Kemerataan

$\mathrm{H}=$ Indeks Keanekaragaman Jenis

$\mathrm{S}=$ Jumlah Jenis

\section{Kepadatan}

$$
\begin{aligned}
K & =\frac{\text { Jumlah jenis }}{\text { Luas }} \\
K & =\frac{\text { Jumlah jenis }}{(20 m \times 20 m \times 25) / 10.000} \\
K & =\frac{\text { Jumlah jenis }}{1}
\end{aligned}
$$

\section{Indeks Dominansi}

Untuk mengetahui Dominansi jamur yang terdapat di areal penelitian maka digunakan rumus menurut [5]:

$$
I D=\Sigma\left(\frac{n i}{N}\right)^{2}
$$

Keterangan :

$$
\begin{aligned}
& \text { ID = Indeks Dominansi } \\
& \text { ni = Jumlah Individu Tiap Jenis } \\
& \mathrm{N}=\text { Jumlah Individu Seluruh Jenis }
\end{aligned}
$$

\section{Hasil dan Pembahasan}

\section{Jamur Basidiomycetes Yang Ditemukan di Taman Nasional Sebangau}

Berdasarkan hasil pengamatan di lapangan, ditemukan 49 jenis jamur dari 15 famili/suku yakni Ganodermataceae, Polyporaceae, Entolomataceae, Thypullaceae, Auriculariaceae, Pleurotaceae, Cortinariceae, Tricholomataceae, Boletaceae, Strobilomycetaceae, Hymenochacetaceae, Physalacriaceae, Coprinaceae, Hymenogastraceae dan Fomitopsidaceae, dari 49 jenis terdapat 37 jenis yang teridentifikasi sampai genus dan 12 jamur yang teridentifikasi sampai species yakni Inonotus diverticuloseta Pegler, Auricularia aurucula-judae, Auricularia auricula, polyporus cf.grammochephalus, Oxyporus latemarginatus (Durieo \&Mont.) Donk., Nigroporus vinosus (Berk) Murr., Polyporus tricoholoma Mont., Rhodofomitopsis feei (Fr.) B.K. Cui, M.L. Han \& Y.C. Dai, Earliella scabrosa (Pers.) Gilb.\&Ryvarden, Strobilomyces confusus Sing, Ganoderma applanatum dan Coriolus versicolor.

Dominansi 10 jenis jamur mulai dari Auricularia auricula (0,142652), Typula sp. (0,00658), Ganoderma sp.13(0,004016), Galerina sp.(0,00257), Coriolus versicolor (0,001968), Inonotus diverticuloseta Pegler(0,001968), Auricularia auricula-judae(0,001446), Ganoderma sp.5(0,001446), Trametes sp.4 (0,000777) dan Ganoderma sp.16 (0,000643).

\section{Kelimpahan Jamur Basidiomycetes Di Kawasan Punggualas}

Berdasarkan hasil analisis untuk kelimpahan jenis jamur Basidiomycetes di kawasan Punggualas dapat diketahui dari indeks kekayaan, indeks keanekaragaman dan indeks kemerataan. Indeks kekayaan jenis diperoleh nilai indeks $\mathrm{R}=7,1956$ dimana berdasarkan kriteria jika $\mathrm{R}>5$ maka kekayaan jenis tergolong tinggi, ini berarti bahwa kekayaan jenis jamur Basidiomycetes di kawasan Punggualas tergolong tinggi. Indeks keanekaragaman diperoleh nilai indeks $\mathrm{H}=2,6260$ berdasarkan kriteria $\mathrm{H}=2-3$ maka keanekaragaman jenis tergolong sedang artinya bahwa keanekaragaman jenis jamur Basidiomycetes yang ditemukan di kawasan penelitian Punggualas cukup terwakili dari masing-masing famili/suku. Sama halnya dengan keanekaragaman jenis, 
untuk kemerataan jenis diperoleh nilai indeks $e=0,6747$ berdasarkan kriteria jika e $=0,3-0,6$ maka kemerataan jenis tergolong sedang ini berarti bahwa jenis-jenis jamur Basidiomycetes yang ditemukan di kawasan penelitian tidak selalu ditemukan di setiap jalur pengamatan. Hal ini diduga terkait pula dengan kondisi iklim pada saat dilakukan penelitian yang telah memasuki musim kemarau. Suhu udara rata-rata berkisar antara $25-37^{\circ} \mathrm{C}$ dan kelembapan berada di sekitar $50-65^{\circ} \mathrm{C}$ sehingga jenis-jenis jamur yang tumbuh kebanyakan dari famili Polyporaceae dan Ganodermataceae yaitu jamur-jamur yang tubuh buahnya berkayu, tebal dan kasar yang dapat beradaptasi pada kondisi setempat. Pada dasarnya jamur akan tumbuh baik dalam kondisi kelembapan yang tinggi. Jamur makro dapat tumbuh optimum pada suhu $20-30^{\circ} \mathrm{C}$ dan kelembapan ideal yang dibutuhkan berkisar antara $80-90^{\circ} \mathrm{C}$. Namun pada umumnya suhu, kelembapan dan intensitas cahaya untuk pertumbuhan jamur makro berbeda-beda tergantung dari masing-masing species jamur makro [6]. Selain itu banyak jamur yang ditemukan sudah dalam kondisi kering/mati. Menurut Suriawiria (1986), jamur yang ditemukan dalam kisaran temperatur $25-37^{\circ} \mathrm{C}$ dengan temperatur optimum $30^{\circ} \mathrm{C}$ tergolong jamur mesofilik [7].

Substrat jamur tumbuh kebanyakan adalah pada kayu (pohon) yang telah mati, hanya ada beberapa jamur yang tumbuh di pohon yang masih hidup dan sebagian lagi tumbuh di tanah. Ini menandakan bahwa lokasi penelitian adalah hutan sekunder yang pernah mengalami penebangan, sehingga jenis jamur yang ditemukan sebagian besar tumbuh/hidup pada kayu lapuk/mati. Hal ini diperkuat oleh pernyataan Mardji dan Soeyamto yang menyatakan bahwa kebanyakan jamur yang ditemukan tumbuh pada kayu mati berasal dari hutan yang telah mengalami penebangan, sementara jamur yang ditemukan tumbuh di tanah, sebagian besar adalah jamur pembentuk mikoriza pada umumnya hidup pada hutan yang belum mengalami penebangan (hutan primer).

\section{Pemanfaatan Jamur Oleh Masyarakat}

Jamur kelas Basidiomycetes yang ditemukan di kawasan Punggualas yang dimanfaatkan sebagai jamur pangan diantaranya adalah jamur Tiram (Pleurotus sp.) yang dikenal dengan bahasa daerah Dayak Ngaju "kulat puti". Jamur ini tumbuh pada kayu Tutup kabali (Diospyros pseudomalabarica). Jamur Kuping "kulat bitak" (Auricularia auricula) ditemukan tumbuh pada kayu Sagagulang (Blumeodendron tokbrai Bl.) dan kayu Parut (Calophyllum pisiferum Planchon \& Triana). Muchroji dan Cahyana, (2008); Chang dan Milles (1989) menyatakan bahwa jamur kuping memiliki kandungan yang sangat tinggi dengan komposisi air 89,1\%, protein 4,2\%, lemak 5,3\%, karbohidrat 2,8\%, serat 19,8\% dan 4,2\% kalori $351 \mathrm{mg}$ [6], [8].

Jamur-jamur yang ditemukan tumbuh pada kayu Kulat (Stemonurus scorpioides) Becc., kayu Tutup kabali (Diospyros pseudomalabarica), kayu Pampaning (Lithocarpus sp.), kayu Ehang (Diospyros siamang Bakh.), kayu Bangkinang balawau (Elaeocarpus sp.), kayu Piais (Nephelium maingayi Hiern.) dan kayu Kajunjung (Cryptocarya griffithiana Wight, Icon). Jamur yang dapat di konsumsi untuk obat adalah jamur Ganoderma applanatum yang dapat menghasilkan senyawa antimikroba yang bersifat sebagai antibakteri, antifungal, maupun antivirus. Gandjar et all., (2006) menyatakan bahwa Ganoderma spp. merupakan jamur yang memiliki sifat hidup annual tumbuh pada pohon yang masih hidup dan menyebabkan pelapukan awal [9]. Kelompok jamur ini memiliki kemampuan hidup multi yakni sebagai parasit dan sekaligus saprofit. Jamur ini akan menjadi parasit pada bagian tumbuhan sampai tumbuhan tersebut mati, selanjutnya akan berperan sebagai saprofit untuk mendegradasi tumbuhan tersebut. Berdasarkan hasil wawancara dengan penduduk lokal yang turut dalam penelitian ini, bahwa di musim penghujan akan banyak ditemukan jenis-jenis jamur yang dapat dikonsumsi oleh masyarakat diantaranya adalah "kulat karitip" (Schizophyllum commune) dan "kulat enyak" (Oedemansiella sp.), "kulat mata pelanduk" (Tremella enchephala) yang dapat pula digunakan sebagai obat penurun panas, jamur arak tupai dapat digunakan sebagai penawar racun/bisa serta obat flu. 


\section{Kesimpulan}

Berdasarkan jumlah individu maka jamur Aucularia auricula merupakan jamur yang dominan tumbuh di Taman Nasional Sebangau. Indeks keanekaragaman $\left(\mathrm{H}^{\prime}\right)=2,6260$ tergolong sedang. Indeks kekayaan $\mathrm{R}=7,1956$ tergolong tinggi dan indeks kemerataan $\mathrm{E} 1=0,6747$ tergolong sedang. Jamur Auricularia auricula (jamur kuping/kulat bitak) dan Pleurotus sp. (jamur tiram/kulat puti) termasuk jamur yang dapat dikonsumsi dan jamur Ganoderma applanatum termasuk jamur yang dapat digunakan sebagai bahan obat. Substrat jamur .

\section{Referensi}

[1] Imazeki, R.; Y. Otani dan T. Hongo. 1998. Fungi of Japan. Yama-Kei Publishers Co., Ltd. Tokyo, Japan. $622 \mathrm{~h}$.

[2] Laessǿe, T. 1998. Mushroom. Dorling Kindersley Ltd., London. 304 h.

[3] Nonis, U. 1982. Mushrooms and Toadstools. A Colour Field Guide. David and Charles, London. $229 \mathrm{~h}$

[4] Bigelow, H.E. 1979. Mushroom Pocket Field Guide. Macmillan Publishing Co. Inc., New York. $117 \mathrm{~h}$.

[5] Indriyanto. 2006. Ekologi Hutan. Bumi Aksara. Jakarta, Indonesia

[6] Muchroji \& Cahyana. 2008. Budidaya Jamur Kuping. Depok: Penebar Swadaya

[7] Suriawiria, U. 1986. Pengantar untuk Mengenal dan Menanam Jamur. Angkasa, Bandung. $210 \mathrm{~h}$.

[8] Chang, S. T., \& Miles, P. G. (1989). Edible mushroom and their cultivation. Florida: CRC Press.

[9] M. Gandjar, I., W. Sjamsuridzal, dan A. Oetari. 2006. Mikologi Dasar dan Terapan.Yayasan Obor Indonesia. Jakarta. 